\title{
An Empirical Study of the Impact of FDI, JVs and Trade on Domestic Technology Stock of India
}

\author{
Bharath Supra, Siddhartha Kushwaha \\ IBS-Hyderabad, The ICFAI Foundation for Higher Education, Hyderabad, India \\ Email: bharathsupra.research@gmail.com
}

How to cite this paper: Supra, B. and Kushwaha, S. (2019) An Empirical Study of the Impact of FDI, JVs and Trade on Domestic Technology Stock of India. Theoretical Economics Letters, 9, 2314-2323. https://doi.org/10.4236/tel.2019.97146

Received: July 29, 2019

Accepted: September 23, 2019

Published: September 26, 2019

Copyright $\odot 2019$ by author(s) and Scientific Research Publishing Inc. This work is licensed under the Creative Commons Attribution International License (CC BY 4.0).

http://creativecommons.org/licenses/by/4.0/

\section{(c) (i) Open Access}

\begin{abstract}
This research is an effort to empirically understand the relationship among the three modes of International Technology Transfer (ITT) - 1) Foreign direct investment (FDI), 2) joint ventures (JVs) and 3) trade. A common factor as representative of technology stock is derived using a number of scientific journal publications, engineering exports, number of trademark registered and patent filed in India by native as well as foreign applicants. A simple linear regression (using ordinary least square method) is conducted on the technology stock and foreign direct investment, joint ventures and trade indicators. Results represent that FDI, JVs and trade are affecting the domestic technology stock gain. SPSS $17^{\circledR}$ is used for factor analysis and transformation of indicators. EView $6^{\circledR}$ is used to make data set stationary and run regression analysis.
\end{abstract}

\section{Keywords}

International Technology Transfer, FDI, JVs, Trade, Domestic Technology Stock

\section{Introduction}

Prior to 1990, the restricted capacity of Indian firms was maintained by the quota system. The rational for the quota system commonly known as "License Raj" was socialist agenda of central government. In the early 1990s the Indian markets were opened via liberalization, privatization and globalization. This allowed domestic and foreign firms to get access to Indian market. By mid-1990s the Indian economy was fairly open for firms to enhance capacity, introduce new products and raise funds from market (domestic as well as international). The foreign firms were allowed to enter Indian market. These firms enter Indian market via trade in goods and services, FDI, licensing and joint ventures. 
It has been a significant time since Indian market was opened for investments foreign firms (with exception of critical sectors like defense, aerospace and nuclear power). During this period, the presence of international firms is expected to have a significant technology transfer (both intended and spillover). India currently is the $2^{\text {nd }}$ fastest growing economy. It is critical for the policymaker to frame and come up with policies to retain the growth path in critical to the growth of sectors and sunrise sectors. These sectors are technology driven like Biotechnology, pharmaceutical and IT \& ITeS to name a few.

Hence there is an opportunity to understand the impact of international technology transfer due to the presence of international firms on change in domestic technology stock which is leading to the growth of India. At the same time the study will provide insights relevant to creating opportunity for foreign firms to seek their organizational objective of investing in India.

The proposed research is a unique effort to unearth the impact of the three modes of international technology transfer (ITT) - foreign direct investment (FDI), joint venture (JV) and trade (technology import), on domestic technology stock of India. The current paper studies interrelationship among these variables using data from Indian Market for duration 1985 to 2008 as the FDI increased during the period, touched $\$ 47$ billion in the year 2008, and thereafter it has never reached same level and FDI is stable around $\$ 30$ billion $^{1}$. To best of authors' knowledge for the duration, no other study has been conducted to understand relationship among all three potential models for international technology transfer viz. Foreign Direct Investment (FDI), Joint Ventures (JV) and foreign trade. The empirical result in the study supports and contradicts several pre-existing understandings of domestic technology stock of a developing economy which is presented in detail in latter section.

Rest of the paper is organized as follows. Section 2 presents relevant literature review. Section 3 gives methodology used in the paper along with source of data, description on independent variables and dependent variable. Next section Section 4 details our empirical model. Section 5 summarizes results of the study. Finally, conclusions, \& discussion and limitations are given in Sections 6 and 7 respectively.

\section{Literature Review}

Glass and Saggi [1] mentioned international technology transfer as a process of gaining access and successful absorption of technological information of a foreign firm into a domestic firm's production process. Production process could also be service creation process depending on the context of technology transfer. Later Subbarao [2], used term international technology transfer as a process of technological knowledge exchange among organization in different countries. Hence any cross international border exchange of technological competency among firms and the absorption of the said transacted knowledge into processes https://qz.com/india/336356/indias-fdi-inflows-are-back-on-track-but-far-from-the-peak-of-2008/ 
of recipient, due to technology gap among parties, could be termed as International technology transfer. The provider of technology gains-access to resource, market, better efficiency or ownership of a strategic asset in return.

Technology can be transferred among firms and nations by several modes. Few channels of technology are reverse engineering, and public private partnerships [2]. Maskus [3] classifies channels of technology transfer into market and non market channels. Market channel includes trade in goods and services, foreign direct investment, Licensing, joint venture, and cross border movement of personnel. Non market channels are imitation, cross firm manpower departure, spillover, and temporary migration. Foreign Direct Investment (FDI) is traditionally regarded as an organic amalgamation of capital, technology, and management synonymous to technology transfer [4]. FDI is the investment made by investors of foreign origin into host nation due to strategic interests e.g. control of management, control of resources (raw material, supplier etc), control on facility to support home operations. The study conducted by [4] concluded that for firms investing directly into developing nation FDI is prominent model of technology transfer. The other papers also concluded that FDI is one of the key modes of ITT [5]. Contradictory to this result an empirical study by Porterie, Pottelsberghe and Lichtenberg [6] contrasted the results and concluded that the FDI has not contributed to any change in host nation's technological base.

Joint venturing and licensing are the modes of ITT when the owner of technology retains the commercial ownership in host nation, and a party in host nation facilitates the production process or service creation process. This mode is followed either due to government regulations [2] or due to intension of technology owner firm to retain commercial ownership. The empirical research in US-Japan alliance context by Wada [7] shows that joint venture is a more beneficial mode for licensees having JVs with licensors in terms of scope of access to technological knowledge in comparison to only licensing.

UNIDO in its literatures attributes rapid growth rates in south-east Asia to the high rate of technology transfer, acquisition and management. Referring to Miyake [8] it can be stated that technology transfer impacts growth of a nation in three inter-related ways-by increasing productive resource's physical inventory, increase capability of firms to harness existing resources and increase in productivity.

A technology transfer is complete only if absorption of transferred technology into production or service creation process will take place [1]. [9] conducted study and established relationship among international JV's performance and absorptive capacity of host firm. The three dimension of absorptive capacity observed in the study are-understanding external knowledge, assimilating that knowledge, and commercially applying the assimilated knowledge, and observed [10] acknowledged the relationship between technology transfer and absorptive capacity of recipient in their study of firm's Size, technology recipient characteristics and technology transfer in case of international joint ventures.

A sophistication of market parameter is observed by Davidson [11] and was 
measured by literacy rate and proportion of urban area population. The absorptive power of host is a reason for any change in technology stock of hosting nation due to presence of foreign player in host market. The technology stock is called R\&D stock in research conducted by [6] where they are observing FDI's effect on technology transfer to host and increase in its technology base. The researchers has found that absorptive capacity have a significant effect on technology transfer [12]. Hence an increase in technical knowledge is expected in a nation as a result of technology transfer.

A peculiar observation made while conducting literature review is that none of the literature dealt with FDI, JV and trade in unison. The three modes of technology transfer exist together in any host market. An opportunity and need is identified here to study the effect of FDI, JV and trade on ITT. India being a growing economy interesting and valuable insights can be obtained for implementing the results of proposed research in other emerging economy. In Figure 1 , the paper's hypothesis is graphically represented.

Hypothesis. There will be a positive association between increase in domestic technological stock and three modes of international technology transfer i.e. FDI, $J V$ and trade.

\section{Methodology}

\subsection{Variables and Data}

The data pertaining to the variables selected for the proposed study is for the period of 25 years viz. 1985 to 2008 on annual basis. FDI to India has increased during the period, reached its peak of $\$ 47$ billion in the year 2008 , and thereafter it has remained stable around $\$ 30$ billion $^{2}$.

\subsection{Dependent Variable}

The dependent variable is a factor representative of technology stock. The technology transfer is a flow variable by its definition as process of gain in technological

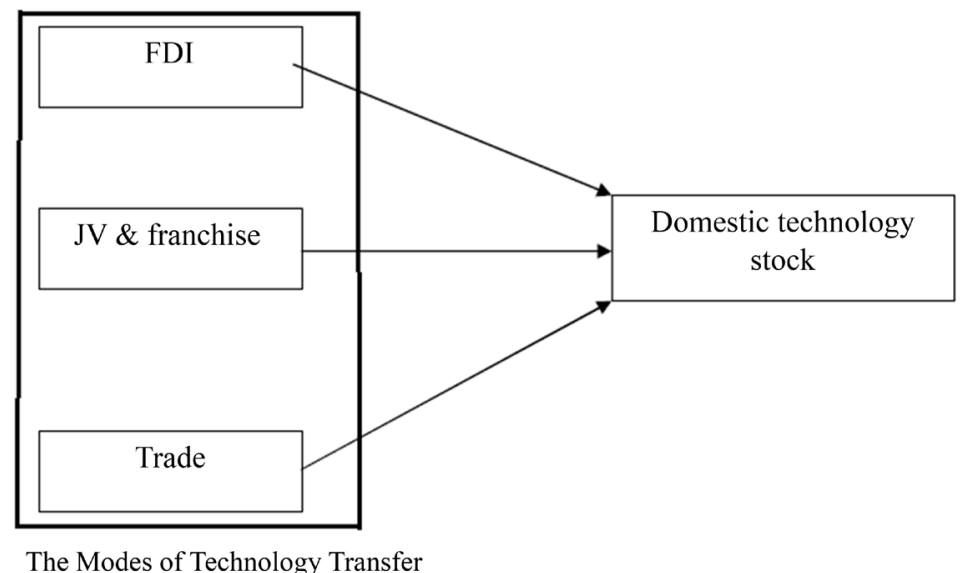

Figure 1. Hypothesized conceptual model.

${ }^{2}$ https://qz.com/india/336356/indias-fdi-inflows-are-back-on-track-but-far-from-the-peak-of-2008/ 
knowledge and its absorption. For the study the annual data (increment in technology stock every year) pertaining to number of scientific publications made in journals, number of trademarks registered in India, engineering product exports and patent filed by in India of native Indian and foreign origin [2] [13] with 8 year of life of patents [14] (from world bank dataset).

\subsection{Independent Variable}

The independent variables are FDI in India (measure used by [1] [4] [5] [6]), JVs in India reflected by royalty and license fee (measure used by [7] [9] [10] [15]) and trade (technology import) of India (measure used by [13]) is tapped from indiastat online database and world bank dataset.

\subsection{Modeling Method}

The study is to understand association or dependence of technological stock on FDI, JVs and trade. Three independent and one dependent variable will be in final model. The measurement scale of variables is metric. Hence multiple regressions are selected as analysis technique. [16] The analysis techniques used by literature relevant in the research question uses multiple regressions [9] [17]) with log-log model ([10] [12] [17] [18]) supporting researcher's decision to use multiple regression with log-log model.

\section{Model}

\subsection{Technology Stock}

Literature review shows that technology stock is constituted by patent, high technology imports, FDI and publications made as result of researches. Factor analysis is conducted on the annual data of the variables as mentioned in the preceding section, to estimate the technology stock. Table 1 shows the results of KMO measure of sampling adequacy and Bartlett's test of sphericity which allowed us to proceed further for factoring the variables.

Table 2 shows the total variance explained by the factors. The principle component analysis is used for extraction. All the four variables are loaded into one single factor for technical stock as indicated by literature review conducted.

The factor score are obtained using regression. There are values of factor loading which are negative. Literature reviewed has determined log-log relationship in technology stock related regression models. Hence in order to take $\log$ of factor scores obtained, factor scores are squared and then log is taken.

Table 1. KMO and Bartlett's test.

\begin{tabular}{lcc}
\hline Kaiser-Meyer-Olkin Measure of Sampling Adequacy. & 0.569 \\
\hline & Approx. Chi-Square & 163.848 \\
Bartlett's Test of Sphericity & df & 6 \\
& Sig. & $0.000^{*}$ \\
\hline
\end{tabular}

*5\% significance level. 
Table 2. Total variance explained.

\begin{tabular}{ccccccc}
\hline \multirow{2}{*}{ Component } & \multicolumn{3}{c}{ Initial Eigenvalues } & \multicolumn{2}{c}{ Extraction Sums of Squared Loadings } \\
\cline { 2 - 6 } & Total & \% of Variance & Cumulative \% & Total & \% of Variance Cumulative \% \\
\hline 1 & 3.008 & 75.197 & 75.197 & 3.008 & 75.197 & 75.197 \\
2 & 0.955 & 23.869 & 99.066 & & & \\
3 & 0.031 & 0.781 & 99.847 & & \\
4 & 0.006 & 0.153 & 100.000 & & \\
\hline
\end{tabular}

\subsection{Domestic Technical Stock Model}

Unit root test.

The data used for the empirical analysis in the study is time series data. Literature acknowledges the problem of non stationarity in time series data which could lead to spurious results and misleading interpretations [18]. Augmented Dickey-fuller unit root test for identifying stationary is being conducted on independent variables using EView6 software. Using the test results in several successive iterations the variables are made stationary. Variable transformation is also done using SPSS 17 software whenever needed in due course of process. Finally stationary forms of data are as shown (Table 3).

The independent variables are found to be non stationary. This indicates that relationship under investigation could be spurious. So difference forms are checked and independent variables are made stationary. The theoretical underpinning clearly and strongly justifies the relationship in question will not be spurious.

\subsection{Empirical Model}

The regression model is developed using ordinary least square method. The model development is started with the stationary forms of variables. To extract best interpretation out of data multiple iterations of regression model estimation is held. The most suitable model is as follows:

$$
\mathrm{TechStk}=\beta_{0}+\beta_{1} \mathrm{FDI}+\beta_{2} \mathrm{Roy}+\beta_{3} \operatorname{Imp}+U
$$

where,

TechStk $=$ technical stock $=$ sum of logarithms of top three loaded variables $(8$ year cumulative sum of number of patent filed, engineering exports and trademark applications in India)

Table 3. Functional forms of variables.

\begin{tabular}{ccrc}
\hline Variable & Transformed form & ADF Test Statistic & Critical Value \\
\hline FDI & Difference $((\log (\mathrm{FDI})), 1)$ & -5.697414 & $-3.769597^{*}$ \\
License fee \& Royalty & Difference $(\log ($ License fee \& royalty), 1) & -3.712217 & $-2.998064^{* *}$ \\
Technological Import & Difference (log(Import), 1) & -3.548078 & $-3.004861^{* *}$ \\
\hline *at 1\% significance level, ${ }^{* *}$ at 5\% significance level. &
\end{tabular}


FDI $=$ foreign direct investment in India

Roy $=$ royalty and license fee paid

Imp = technology product imports

$\mathrm{U}=$ Disturbance term

$\beta_{0}, \beta_{1}, \beta_{2}$ and $\beta_{3}=$ Parameters to be estimated

The estimated model is not purely log-log equation. Although under the issue of stationarity the model is acceptable on the conceptual grounds developed from literature review.

\section{Results}

Regressions were run on the models using the data compiled for a period of 25 years in EView6 ${ }^{\circledR}$ software. Table 4 presents the most satisfactory results obtained from functional forms of variables (Table 3 ).

The FDI shows a positive impact on domestic tech stock. The royalty and license fee are having a positive effect on domestic tech stock of India. The variable technology product import is also showing positive relationship with technology stock. All the three modes of technology transfer are influencing domestic technology stock significantly statistically significant.

Adjusted R square delineates the good model fit. The Durbin Watson value is lying into zone of indecision (d-statistic: 0.682 to 1.776 for $\mathrm{df}=25$ and $\mathrm{k}=6$ ) regarding auto correlation. Hence no comment can be made regarding autocorrelation among variable error terms.

\section{Conclusion \& Discussion}

Referring to the results FDI inflow in India is contributing to the domestic knowledge stock. The result refutes the empirical study by [6] and its results. This strengthens the literature of international technology transfer which is affected by the FDI in host country in south Asian and emerging economies context. Simultaneously the result consolidates the common assumption that FDI is one of the key modes of ITT in literature [1] [2]. Hence two school of ITT can be identified here. One where FDI is causing ITT in turn increasing technology stock of host country and the other school where FDI is not affecting the technology base of host country.

Table 4. The most satisfactory results.

\begin{tabular}{cccccc}
\hline Variable & Parameter & t-statistic & Sig. & Adjusted R ${ }^{2}$ & d-Statistic \\
\hline Intercept & -2.575199 & -5.495789 & 0.0027 & & \\
Foreign direct investment & 1.709043 & 3.038884 & 0.0288 & & \\
$\begin{array}{c}\text { Royalty and license fee } \\
\text { paid }\end{array}$ & 3.360568 & 2.780839 & 0.0389 & 0.768620 & 1.764497 \\
$\begin{array}{c}\text { Technology product } \\
\text { imports }\end{array}$ & 5.673318 & 3.226589 & 0.0233 & & \\
\hline
\end{tabular}

*5\% Significance Level. 
Further this study is conducted in Indian context which is an emerging economy. Thus result of supports the earlier study of [4] where it was concluded that FDI into developing nation FDI is a prominent model of technology transfer.

The positive effect of royalty and license fee paid by franchisees and licensees in India indicates the royalty and license fee payment has increased over time with increase in domestic technology stock. This could be interpreted as the increase in technical stock increases the technical proficiency of host nation. In subsequent time periods a better and advanced technology will be demanded hence more license and royalty fee will be needed to be paid to a technology exporting nation. The result of the study contradicts the result of study by [9].

The conducted effect of technology imports on tech stock can be interpreted such as when technology import increases the domestic technology stock gets accesses. Modification, adaptation and assimilation for business objective of the gained technological knowhow lead to increase in host nation tech stock generation capability. Host countries do not have to make investment for developing the base technological competency.

The statistically significant negative intercept brings forward the fact that in the absence of ITT the domestic stock of a nation will be depleted because of underdeveloped technological capabilities of emerging economies could not sustain the market forces and the R\&D efforts will die out in absence of support.

The conducted study also supports the results of [10] that technology transfer increases the capability of firms to harness existing resources i.e. one of the element of domestic knowledge stock-assimilation of knowledge for commercial purpose.

The d-statistic fell in zone of indecision. Hence statistically no comment on the presence of autocorrelation can be made. This could be attributed to the interrelated characteristic of the three modes of ITT. The three modes-FDI, JV and trade, always exist together. Firms of foreign origin decide the trade off among the mode of business in a host nation depending on the regulatory requirement and corporate objective. Hence multicollinearity and autocorrelation consolidates the existence of decision trade off.

High multicollinearity and autocorrelation are expected by the data set. The presence of these phenomena will inflate the numerical value of the impacts these three modes are putting on domestic tech stock. Although the objective of the study is concentrated on understanding the nature of affect mode of ITT implicate on domestic technology stock.

\section{Limitations and Scope of Future Research}

The study is conducted in Indian context. India is a major participant in south-east Asia and emerging markets. The results of the study are needed to be validated in other emerging economy nation.

The study is focused only to understand the nature of relationship among modes of ITT-FDI, technology trade and Joint ventures, and domestic technol- 
ogy stock. A more elaborate study is suggested for the further exploration using larger data set, identifying the dynamic relationship among the modes of ITT, more accurate estimation of life of patent and trade mark and with other key variables of technology stock like number of researchers, and number of journal publications. A cross country and cross industry analysis will lead to more in depth understanding of the ITT and domestic technology stock. Industry specific study will aid more to business community in terms of support to business decision making, academics in term of better understanding the environment and domestic policy makers in proper trade off while drafting and imposing pertaining to international technology transfer issues.

We identified that the availability of suitable and sufficient data is problematic. In absence of which we limited our study to only understanding the relationship among modes of ITT and domestic knowledge stock. A more elaborate study needs better data set.

\section{Conflicts of Interest}

The authors declare no conflicts of interest regarding the publication of this paper.

\section{References}

[1] Glass, A. and Saggi, K. (2009) The Role of Foreign Direct Investment in International Technology Transfer. In: Dutt, A. and Ros, J., Eds., International Handbook of Development Economics, Edward-Elgar, Cheltenham.

[2] Subbarao, P.S. (2008) International Technology Transfer to India-An Impedimenta \& Impetuous. W.P. No. 2008-01-07.

[3] Maskus, K.E. (2004) Encouraging International Technology Transfer. UNCTAD-ICTSD Project on IPRS and Sustainable Development. Paper No. 7. https://doi.org/10.7215/IP_IP_20040501A

[4] Cheng, L.K. and Kwan, Y.K. (2000) What Are the Determinants of the Location of Foreign Direct Investment? The Chinese Experience. Journal of International Economics, 51, 379-400. https://doi.org/10.1016/S0022-1996(99)00032-X

[5] Kamal, S. (1996) Entry into a Foreign Market: Foreign Direct Investment versus Licensing. Review of International Economics, 4, 99-104. https://doi.org/10.1111/j.1467-9396.1996.tb00087.x

[6] van Pottelsberghe de la Porterie, B. and Lichtenberg, F. (2001) Does Foreign Direct Investment Transfer Technology across Borders? The Review of Economics and Statistics, 83, 490-497. https://doi.org/10.1162/00346530152480135

[7] Wada, T. (2001) Equity Joint Ventures and the Scope of Knowledge Transfer between Diversified Firms: Evidence from U.S.-Japan Alliances. Faculty of Economics, Gakushuin University, Tokyo, Japan.

[8] Miyake, T. (2005) International Technology Transfer. CACCI Journal, 2.

[9] Lane, P.J., Salk, J.E. and Lyles, M.A. (2001) Absorptive Capacity, Learning, and Performance in International Joint Ventures. Strategic Management Journal, 22, 1139-1161. https://doi.org/10.1002/smj.206

[10] Sazali, A.W., Haslinda, A., Jegak, U. and Raduan, C.R. (2010) MNCs' Size, Tech- 
nology Recipient Characteristics and Technology Transfer in International Joint Ventures. Research Journal of International Studies, 13, 17-31.

[11] Davidson, W.H. (1985) Key Characteristics in the Choice of International Technology Transfer Mode. Journal of International Business Studies, 16, 5-21. https://doi.org/10.1057/palgrave.jibs.8490448

[12] Kneller, R., Panteal, S. and Upward, R. (2010) Does Absorptive Capacity Affect Who Benefits from International Technology Transfer? European Trade Study Group 2010 12 th Annual Conference, Lausanne, 9-11 September 2010.

[13] Watson, F., Johnstone, N. and Haščič, I. (2009) Using Patent Data as an Indicator of International Technology Transfer. World Bank Research Observer, 17, 191-235.

[14] Couch, D. (2009) Patent Law Analysis-USPTO Maintenance Fees. Patent Law Blog (Patently-O). http://www.patentlyo.com/patent/2009/02/uspto-maintenance-fees.html

[15] Lopez, R.A. (2007) Foreign Technology Licensing, Productivity, and Spillovers. World Development, 36, 560-574. https://doi.org/10.1016/j.worlddev.2007.04.016

[16] Hair Jr., J.F., Black, W.C., Babin, B.J., Anderson, R.E. and Tatham, R.L. (2006) Multivariate Data Analysis. 6th Edition, Pearson Prentice Hall, Upper Saddle River, NJ.

[17] Branstetter, L.G., Fisman, R. and Foley, C.F. (2004) Do Stronger Intellectual Property Rights Increase International Technology Transfer? Empirical Evidence from U.S. Firm-Level Panel Data. https://doi.org/10.3386/w11516

[18] Park, J., Shin, S.K. and Sanders, G.L. (2007) Impact of International Information Technology Transfer on National Productivity. Information Systems Research, 18, 86. https://doi.org/10.1287/isre.1070.0116 